\title{
Climate Communication Society Organizations in the Development in the Village Plompong
}

\author{
Muhammad Luthfie \\ Djuanda University, Indonesia \\ E-mail: mluthfie25@yahoo.com \\ Aida Vitayala S Hubeis \\ IPB University, Indonesia \\ Amiruddin Saleh \\ FEMA IPB University, Indonesia \\ Basita Ginting \\ FEMA IPB University, Indonesia
}

Received: July 28, 2016 Accepted: August 14, 2016 Published: August 15, 2016

doi: 10.5296/jsss.v4i1.9894 URL: http://dx.doi.org/10.5296/jsss.v4i1.9894

\begin{abstract}
Climate Communication in an organization is very important to foster togetherness and unity. Climate conducive communication between the leaders and members or between superiors and subordinates can achieve harmonization within the organization that will ultimately reap success in the implementation of its programs. The ideal climate organizational communication requires honesty in communication, openness of communication down, and a joint decision. Pace and Faules (2000) states that organizational communication climate is important for linking organizational context with concepts, feelings, and expectations of the organization's members and to help explain the behavior of members. The study aims to analyze the communication climate organization built community organizations in rural
\end{abstract}




\section{Ml Macrothink}

Journal of Social Science Studies

ISSN 2329-9150

2017, Vol. 4, No. 1

development. The results showed climate communication community organizations research subject is very conducive and riel has been able to encourage active involvement in the development in the village Plompong, through the realization of its programs in the construction of infra structure.

Keywords: organizational communication climate, togetherness, honesty, openness

\section{Preliminary}

Community organizations need a communication climate that is conducive to realizing the togetherness and openness. Climate that supports organizational communication will provide the ability for organizations to realize the society institutionalized work programs. Organizational communication climate is the situation in the working environment in an organization as a whole. Good organization can be achieved if there is good communication climate, demonstrating the harmonization of communication between leaders and members, between superiors and subordinates, between leaders, or among members.

The existence of communication climate is important, because the organizational climate can affect the way of life of its members, to whom to speak, who is favored, how the activities how it works, how it goes, what it wants to achieve and how to adapt. Many research results which indicate that the organizational climate is far more important than skills or communication techniques solely in creating an effective organization.

Relations with the communication that took place between superiors and subordinates, subordinates to superiors, and between subordinates and subordinates in an organization is a picture communication climate that is very influential in the creation of bridging the increase in labor productivity in the organization. Organizational communication climate can affect job satisfaction and work motivation member or employee in an organization.

According Yoanne (2013) organizational communication climate is a function of the activities contained in the organization to demonstrate to members of the organization that the organization trust them and give them the freedom to take risks; encourage them and give them responsibility in doing their tasks and provide information that is open, and just about the organization; listened attentively and obtain information that can be trusted and frankly of the members of the organization; actively providing information to members of the organization so that they can see that their involvement is important for decision-making in the organization; and pay attention to the work of high quality and challenging.

Associated with the correlation between climate organizational communication, Pace and Faules (2000), states that another reason that supports the importance of communication climate organization is due to the climate of organizational communication conducive, comfortable and positive, it is believed will increase the motivation of the members of the organization or employee. Work motivation is something that stimulation or morale, or in other words morale booster. Another factor that can affect employee motivation is a factor of job satisfaction. As'ad (2001) explained that job satisfaction is an assessment of how much the work as a whole is able to satisfy their needs and the feelings of employees towards work. Job satisfaction is also a process of achieving the level of motivation of members or employees to be more productive at work and is a form of workmanship that is driven by the fulfillment of his needs. 


\section{Ml Macrothink}

There are eight factors that stable of communication satisfaction. These factors are (1) Climate communication, (2) Communications supervision, (3) Integration of the organization, (4) quality of the media, (5) Communication with colleagues, (6) Information of companies,

(7) Feedback individuals, (8) Communication superiors and subordinates (Arifin, 2005).

Organizational communication climate is a broad concept that is known to members of the shared perception of the nature or character of the workplace; This is an internal characteristic that distinguishes one organization to another and influence the people in the organization. Davis and Newstrom (2003) states that organizational climate can be in one place on a continuum that moves from pleasant to neutral until the unpleasant. Bosses and employees want a more pleasant climate for maslahatnya, such as better performance and job satisfaction.

According to Pace and Faules (2000), there are six factors that affect organizational climate, all of which is done through a process of communication, namely:

1). Trust. Individuals at all levels should strive to develop and maintain a relationship in which there is trust, confidence, and credibility and supported by statements and actions.

2). Making decisions together. Employees at all levels in the organization should be invited to communicate and consult on all issues in all areas of the organization's policies, which are relevant to their position. Employees at all levels must be given the opportunity to communicate and consult with management over them in order to participate in the process of decision making and goal setting.

$3)$. Honesty. The general atmosphere that is filled with honesty and candor must determine relationships in the organization, and the employees were able to say "what is in their mind" regardless of whether they are talking to peers, subordinates or superiors.

4). Openness in communication down. Except for the purposes of confidential information, members of the organization should be relatively easy to obtain information directly related to their duties at the time, which affects their ability to coordinate their work with people or other parts, and related extensive with the company, its organization, the leaders, and plans.

5). Listen to the upward communication. Individuals at every level in the organization must listen to suggestions or reports issues raised subordinate personnel at every level in the organization, continuously and with an open mind. Information from subordinates should be deemed important enough to be implemented unless there is evidence that the opposite.

6). Attention to high-performance goals. Personnel at all levels in the organization must demonstrate a commitment to the goals of high-performance, high productivity, high quality, and low cost.

Organizational communication climate showed some general agreement, among other things, the existence of a consensus that the climate of organizational communications are more descriptive than affective or evaluative. Organizational communication climate arising from the practice of the organization is limited to the activity of systematic and influence the behavior of members. Further Jablin (1987) suggests that the various results of research on organizational communication climate measures related to various aspects, among others, the truth, influence, mobility, the desire to interact, direction from superiors, and complacency. 
Organizational communication climate is very influential on the support member, openness, togetherness, trust, and a sense of justice in the organizational environment.

High motivation and job satisfaction are created for their togetherness and harmonization of communication that arise, for their climate conducive organizational communications. Putnam (1983) states, if an organization is considered as a structure, then the communication is a real substance that flows up, down, and sideways in an organization. Organizational Communication climate is relatively timeless quality of an organization's internal environment experienced by its members, affecting their behavior and can be described in terms of values of certain characteristics of the environment (Pangumpia, 2013).

The research problems are how the climate communication developed within the community organization Muhammadiyah as research subjects (hereinafter referred to organizations subject), so as to encourage the existence of the organization and successfully implement its work program well, including being a pioneer in the development in the village Plompong. Based on the formulation of the problem as it was the purpose of research, is to analyze the communication climate organization that built the organization of subjects in rural development, so as to maintain unity, maintaining the existence of the organization, and actively participate in the development in the village Plompong.

\section{Method}

Having a goal to collect data in depth with a strong argument, and the validity of the data is accurate, the study used a qualitative approach that is oriented explanation of descriptive data of the object studied by directing approach-approach on the background and the object is a natural and holistic (whole and complete). Research will build a complex and holistic overview, analyzing the words, informants view detailed reports and conduct research in a scientific setting. Qualitative research approaches based on constructivism. The unit of analysis of research related to communication actions of community organizations that have different characteristics in creating positive symbolic interactionism.

The choice of location research done intentionally (purposive), based on the initial findings of the study related to the working area of the subject organization, the Village Plompong, District Sirampog, Brebes. The preliminary study has been conducted in May-June 2014. Taking full qualitative data was conducted in October-December, 2015.

Agree with Creswell (2012), collection of data in research done by several techniques in accordance with qualitative research approaches, namely: observation, in-depth interviews Focus Group Discussion (FGD), and document research. Data collected in the study are primary and secondary data. Primary data were obtained from informants research, which led the subjects organizations, village heads and other community organizations leaders in the village Plompong, to know the data associated with the formulation of research problems. Secondary data were obtained from the documents and observations.

The data document is a village Monograph Plompong and written data subjects organization. Monograph Plompong village used to describe the characteristic structure of the village and the villagers of Plompong, while data is written from the organization subyekdigunakan for describing the structure and characteristics of that society organization and as a tool to analyze the validity of the data. FGD involving several informants whose credibility is 
undoubtedly related to the object of research, done to strengthen the validity of the data found through other data collection techniques. The participants, is 5 figures subjects organizations have extensive data concerning the subject matter of the study.

To ensure the quality of data validity of qualitative research, researchers noticed authenticy and trustworthyness of the data obtained. This type of technique examination of the validity of data taken is triangulation, which is a technique that utilizes data validity checking something else beyond the data for the purposes of checking or for comparison with the data itself. In line with the thinking Sugiyono (2010), research triangulate the source, triangulation data collection techniques, and time.

Following the theory of Creswell (2012), reliability testing (reliability) is pursued by reference to the three aspects, namely: (1) stability (keajekan), meaning that the focus of study after repetition, gives the same results or saturated, (2) the accuracy or the accuracy of the object studied, (3) homogeneity, seen from a high relevance between the constituent elements of research, and give full understanding of contributions to the problems examined.

Such as those offered by Moleong (2005), the data were analyzed with the process of arranging the order of the data, organize them into a pattern, category, and description of the basic unit. How, sifting through the data into units, mengkategorasikan data based on the themes that emerge, seek and find patterns in accordance with the object of study, and found that important, interpret and reflect and then decide what will be presented in the study. Categorizing data are adjusted with questions and research objectives in order to facilitate the selection, description, interpretation and analytical as material conceptualization, comparison, narrative, and construction. Data processing is done by measuring the data with the theories used research.

\section{Results and Discussions}

Organizations subjects who have leadership at the Village Plompong, District Sirampog, Brebes and selected as the organization of research subjects, is an organization that has different characteristics to the villages, where the organization's activity. Initially, the organization subject Plompong diidirikan in the village on 12 February 1964, vehemently denied by the villagers as seen carrying values vertically and horizontally in contrast to the confidence of local communities. Hard struggle to deal with differences in religious viewpoint (fiqh), through appropriate symbolic interactionism, can ultimately encourage the existence of organizations subject Plompong growing in the village, and in its development, a pioneer in the development in the Village Plompong (Royyani, 2011).

On socialization and activities in the village Plompong, organizations now moving subjects in the field of social, educational and religious has managed to collect 75 percent of the villagers as members or sympathizers (Royyani, 2011). Until 2015, the subject organization has successfully established various institutions (Table 1). 
Table 1. Educational institution community organization of research subjects

\begin{tabular}{lll}
\hline Educational & Social / Religious & Economy \\
\hline MTs Terakreditasi B & Majlis Ta'lim Al Inayah & Employees Cooperative Solar \\
MATerakreditasi B & Majlis Ta'lim Al Barokah & Kopontren Nasikhah Maemanah \\
SMK Terakreditasi B & Majlis Ta'lim Al Muqorrobin & Centralisasi Event Organization \\
TPQ Al Izzah Krajan & Majlis Ta'lim Nurul Huda & \\
TPQ Al Inayah Ciku 1 & Majlis Ta'lim Al Muhlisin & \\
TPQ Al Muhlisin Pc Lancar & \\
TPQ Al Ikhwanul Muslimun & \\
TPQ Nurul Huda Cirendu & & \\
TK ABA 1 & \\
TK ABA 2 & \\
Pondok Pesantren & \\
\hline
\end{tabular}

The existence of educational institutions subject organizations, has increased the number of educational institutions in the village Plompong. TK 3 pieces and 2 pieces belongs to the organization of the subject, SD 3 pieces belonging to other organizations, SMP 3 pieces belonging to other organizations, SMA / SMK 4 pieces and 2 pieces belongs to the organization of the subject. In addition, educational institutions owned by the subject organization has increased the number of Islamic educational institutions in the village Plompong. Raudhatul RA 1 piece belonging to other organizations, Islamic Elementary School 2 pieces belonging to other organizations, MTs 3 pieces and 1 piece belongs to the organization of the subject, Madrasah Aliyah 2 pieces and 1 piece belongs to the organization of the subject, Ponpes 2 pieces and 1 piece belongs to the organization subject,

The results overall show uniqueness, because the rapid development of the priority programs of the Organization subject can be realized in a village. In fact, the subject of a Persyarikatan Organization, known as the urban organization whose existence is known only in the rapidly growing urban areas (Chusnan, 2013). Moreover, the subject organization in the village Plompong just a twig management (management of the lowest unit in the organizational structure of the subject, as a large organization at the national level that have a central leadership). According to Hashim (2000), in many regions within Indonesia, twigs on the subject organization does not exist and the construction was not a priority subject at the head of the organization on a deeper level. Complaints how difficult to find members of the leadership of the branches in each branch deliberations, might have become a classic complaint. But getting to the top levels of the organization, such as a branch, local, regional and central easier to find candidates for members of the leadership. Even the candidates tend to be crowded to exceed the needs of the leadership formation. 


\section{MInstitute Macrothink $_{\text {Int }}^{\text {Intis }}$}

From the preliminary data obtained, the subject of organizational success as a pioneer development in the Village Plompong, because climate conducive organizational communications. Internal communications organization developed by the leadership of the organization of the subject, became the start achieving the outcomes of the work program measurable success. Even today the daily life of the population characterized by the attributes of the subject Organization. The existence of organizations subject at its inception, was introduced through the role of communication in the form of measures appropriate communication, resulting in organizational communication climate conducive to realize the effectiveness of communication.

Effective communication is to facilitate the creation of togetherness within the organization. Herdianto (2010) states, in relation to effective communication, trust is the basis for the creation of teamwork. This trust can only come if you have integrity, that includes things that are more than just honesty. If honesty is telling the truth or adjust our words to reality, integrity adjust reality in words. Integrity is active, while honesty is passive.

Effective communication between elements of the organization, from leaders to subordinates, has created a climate conducive organizational communications in environments subject organization in the village Plompong. Besides being able to encourage the establishment of a reliable working team, organizational communication climate also has clearly embodies unity and engagement in the implementation of the work program / charitable organization business subjects.

From the data obtained, a healthy organizational communication climate, among the leaders and members, and between members of the organization's members in the subject, has been the basis of strengthening the organization's existence in the village Plompong subject. Conditioning climate conducive organizational communication starts from communication policies pursued meet the aspirations of the subject organizational stakeholders. From the start of the placement of the structure that respects seniority or expertise someone, socialization clearly communicated policy, to the fulfillment of adequate welfare.

Ranting organizational communication climate conducive organizations Plompong subjects submitted by Wahibpudin, chairman of the Branch organization Sirampog subjects (interview held on 12,15, October 17, 2015). Since its inception the organization Ranting Plompong subject, organizational communication climate is very guarded. Progress realize the integrity of the elements of the organization, togetherness and mutual intention to develop the message subject in the village Plompong organization in particular, and in the District Sirampog in general.

During served as chairman of the Branch Leadership Organization Plompong subjects for two periods (2000-2005 and 2005-2010), Wahibpudin always maintain organizational communication climate to remain favorable in organizing charitable efforts or work program. The tendency for one-man show is always avoided, and instead give priority to consensus, and "work together". Dialogue and communication with stakeholders always developed to create a sense of organization had the same subject.

Sensitive issues such as conflict of interest between the element manager charitable efforts or financial problems, are always resolved by way of dialogue, deliberation and consensus. Not 
enough with that, head of the Branch Organization Plompong subjects often do with interpersonal communication approach. Communication is instructive always be avoided, except in matters that have been standardized and tersistem.

For example, on the issue of centralization of financial institutions, leadership within the organization subject Plompong start with dialogue, sharing opinions, and formulate together system. Financial accountability so guarded, so that members' and managers Persyarikatan education agency subjects organization strongly believes that policy. That is, anything related to the interests of a good organizational climate and maintain the trust members, always carried out with the communication process (Wahibpudin, interview dated October 17, 2015). In 1986 we were with friends initiated on MTS, used here are concerned there is no MTS her education, there is only SD and MI. When building MTs in 1987, residents help. At the beginning of the establishment of MTs take advantage MI Plompong to be 3 classes and growing. After Madrasah Aliyah established in 1990 and graduated students, and then try to open a dressmaking vocational majors, and automotive and multimedia computer. SMK established in 2003. We continue to establish a boarding school. Accreditation MTS A, Aliyah B, SMK B. MTS 300 students, 100 students Aliyah, SMK 300 Students, 225 boarding school students. 2013-2014 MTS opened a boarding school featured class. To maintain unity in the realization of charitable efforts, we always keep the atmosphere of communication within the organization. During served as chairman of the Branch Chief society organizations Plompong research subject for two periods (2000-2005 and 2005-2010), I always keep organizational communication climate to remain favorable in organizing charitable efforts or work program. The tendency for one-man show is always avoided and prioritizes consensus, as well as "work together". Dialogue and communication with stakeholders always be developed to have the same sense of community Organization research subjects. Sensitive issues such as conflict of interest between the element manager charitable efforts or financial problems, are always resolved by way of dialogue, masyawarah and consensus. Not enough with that, Chief Twig Community organizations Plompong research subjects often do with interpersonal communication approach. Communication is instructive always be avoided, except in matters that have been standardized and tersistem. For example, on the issue of financial centralization educational institutions, community organizations Twig Leaders study subjects Plompong start with dialogue, sharing opinions, and formulate together system. Financial accountability so guarded, so that members' and managers Persyarikatan educational institutions society organizations are subjects of research strongly believes that policy. That is, anything related to the interests of a good organizational climate and maintain the trust members, always carried out with the communication process (Wahibpudin, interview dated October 17, 2015).

Another example, when seeking independent funds to finance charitable efforts or program subject Plompong organizations through agricultural activities, in addition to actively engage the leadership of the board daily, also involving members of the organization subject expert in that field. Mutual recognition capabilities over others, is honesty in communication. So that the control program in the organization's environmental efforts subjects, including education, social and health, are always people who are experts in each of these fields. This is what has always cultivated and used as a perception in the period of leadership at the top. The 
result of business in agriculture that led to the independence of the Organization Plompong subject. All charitable organization business subjects in the village Plompong financed independently of the sale of vegetable crops, led by the chairman of the organization of the subject. In this Plompong there is also one of the pilot projects of the Regional Leadership organization subjects in Brebes regency level in agriculture, namely farming potatoes, carrots, cabbage, peppers, onion and beans. Branch organizations Plompong subject, subsequently determined by the central leadership of the organization as a subject of the Branch of National Model (The Enlightenment, 2016).

The organization's internal communication more often done in dialogue and interpersonal communication. Communication that is instruction or command, is minimized so that the interaction between leaders and subordinates are always intimate, full of understanding and togetherness. 5 Another informant said the same thing when polled about climate communications organization in the Branch Organization subject Plompong, namely Taufik Spd, Drs Tohirin MPd, Solahudin Hernawan Spd, Marzuki Spd, and M Taip Subandi, SPdI (interview held on 12,15, 17 October 2015). The five men were also asked researchers to conduct focus group discusson (FGD) on October 18 and October 19, 2015, to validate the information entered, especially in issues related to organizational communication climate. In fact, Marzuki Spd, who now leads the Branch Organization Plompong subject, stating that the idea of the charitable efforts of the Organization subject always strived to come or came from members of the leadership and not necessarily from the head of a twig.

Acts of communication that create a climate of togetherness such communications, blatantly realize effective communication that produce the same understanding. Wilbur Schramm (Effendy, 1987) says that communication can be more effectively waged, then the message must be designed and delivered in such a way so as to attract the attention of the intended target.

According to the former Minister of Information in the New Order era, Harmoko (1985), in a development, especially in certain areas, it requires effective communication within the same term with contextual communication. The contextual communication tailored to the socio-cultural characteristics of society. With such communication, the message delivered to the audience must be: (1) Arouse their hearts so that ideas and feelings conveyed by messenger already like one belonging to the recipient of the message itself, (2) Potential impetus to act for the target audience spontaneously and full impression.

In the context of the Branch organization subjects in the village Plompong, the effectiveness of communication that comes from communication climate organization that supports, produces deeds of business benefit to members and villagers, while strengthening the existence of the organization subjects in the village Plompong, in districts, counties, provinces, even in national level as twigs exemplary. In education, although Wahibpudin, chairman of the branch is a teacher, but the leadership positions of educational institutions in the village Plompong organizations subject submitted to the other members are considered experts in their field. Wahibpudin himself once was head of the organization MTs Plompong subjects in the village during the leadership of H Mu'min Thoif (1986).

According Wahibpudin (interview dated October 17, 2015), his policy is a form of communication that explains that leadership must be left to experts, and not have to come 
from the board. This view provides a good motivation for the direction of his leadership, and provide open space that is wide enough for teachers organizations subject to express and demonstrate achievement. During the reign of Wahibpudin established Madrasah 'Aliyah organization subjects in the village Plompong (July 15, 1990) with the principal first Drs Cholison (derived from the Branch organization subject Manggis, neighbors Twig organization subject Desa Plompong), and vocational organizations subject Plompong (July 15, 2004) with the principal Fauzan Rome Spd.

With actions such communication that leads people to reach a consensus together to solve a problem or to formulate future organizational communication climate in deeds educational efforts Plompong subject Organization is maintained. The sequel, harmonization embodied in the manager which provides motivation to the development of institutions and the gain of the results of work programs.

During the reign of Wahibpudin recorded 6 pieces formal education institutions well developed, and generate significant revenue to support the independence of the subjects in the Village Branch Plompong organization. The data are as set forth in Table 2 below.

Table 2. Formal educational institutions Subject Organization Plompong

\begin{tabular}{lllll}
\hline No & School & Headmaster & Education & $\begin{array}{l}\text { Accreditation/ } \\
\text { The number of students }\end{array}$ \\
\cline { 2 - 5 } 1 & TK ABA Plompong 1 & Aini Inayati & D2 & $-/ 59$ students \\
2 & TK ABA Plompong 2 & Umi Zuhanah & MA & $-/ 37$ students \\
3 & MTs & Solahudin Hernawan SPd & S1 & B/ 465 students \\
4 & MA & Drs Tohirin MPdI & S2 & B/356 students \\
5 & SMK & Taufik SPd & S1 & B/304 students \\
6 & Pondok Pesantren & M Taip Subandi SPdI & S1 & Students MTs, MA and SMK \\
\hline
\end{tabular}

Marzuki, the head of the subject in the Village Branch organization Plompong period 2010-2015, when interviewed by November 1, 2015 has informed that participation in village development organization subject Plompong through deeds of an organization's business subjects who successfully built and appreciated by the public, due to the their sound organizational communication climate. In the process, the communication is done through the delivery of quality messages (think are ripe before it is submitted), always deliver the benefits to be obtained and submitted wisely and clearly (bilhikmah). Communication or proselytizing bilhikmah as taught by Prophet Muhammad, taught the process of delivering a message to the ethical, clear and easily understood by the recipient of the message. The aim is that messages can be received well and create a common understanding between the message (communicator) and who received the message or the communicant (interview on 2 November 2015).

Effectiveness of communication, according to another informant in the Branch Chief in the village organization subject Plompong (Drs Tohirin MPd, Solahudin Hernawan Spd, and M 


\section{Macrothink}

Taip Subandi, interviews on 2 and 3 November 2015), is always based on communication bilhikmah. With bilhikmah, then all the process of delivering the message conveyed by the guidance of the Prophet, do not patronize, clear and produce a common understanding between the elements that communicate. All three informants confirms, bilhikmah communication, organizational communication climate to realize the full unity and brotherhood, with no one feel excluded.

In the process, communications internal organization conducted by the Chairman of the Branch organization of the subjects in the village Plompong (interview Wahibpudin, November 3, 2015), is not patterned on one-way communication (monologue), but always developed in the communication patterns of dialogue, although his ideas sometimes come from the top the leadership of the organization branch of the subject. Participation of both parties to jointly analyze the understanding of the message (convergent communication patterns), and not just come from a single participant occurs continuously and the information sharing process is advantageously between two or more people. Thus, concurrent with the completion of the communication process, manifest also a shared understanding (effective communication). This reinforces togetherness in keeping climate conducive organizational communications.

The above description indicates the presence of organizational communication climate that supports positive dynamics in the Village Branch organizations subject Plompong, in carrying out its program of work to build a business deeds. Organizational communication climate as it has been pointed out to members of the organization of the subject, that the organization trust them and give freedom to take risk; encourage and give them responsibility for tasks and providing open information about the organization; listened attentively and obtain information that can be trusted and frankly of the members of the organization; actively providing information to members of the organization so that they can see that their involvement is important for decision-making organization; and paying attention to the work of a high quality and continues to provide a challenge for the organization's progress.

In organizational communication in the external environment, the organization's leaders in the village Plompong subject always to communicate with the spirit of brotherhood and communications on behalf of his fellow villagers. Communication outside the organization was always done by removing the jacket of the organization, and blend together as one village. The data presented by Wahibpudin (interview dated October 18, 2015). The goal, is that there are no barriers between villagers in the end the villagers, including members of the organization of the subject, the focus of the common good that is in charge of development in the village Plompong.

FGD results on 2 and 3 November 2015, involving five figures organizations subject (Taufik, Tohirin, Solahudin Hernawan, Marzuki, and M Taip Subandi, stating that the choice of communication with the spirit of brotherhood and communications on behalf of his fellow villagers, was real realize togetherness among the villagers to have a concern that converge in development in the Village Plompong, while maintaining unity as the villagers. the act of communication to create a climate of communication external organizations like it, ultimately reducing the barriers due to differences in the characteristics, and on the other hand gave birth 
to a deal -kesepakatan further among the villagers, as many villagers were finally willing to become members of the organization in the village Plompong subject.

In some areas, organizations subject knit good communication difficulties and develop organizational climate conducive external communication with villagers or community organizations that are similar but different views. For example, served on the research results Rahardjo (2007) on the conflict between the NU and Muhammadiyah 1960-2002 which describes the conflict between NU and Muhammadiyah in Yogyakarta Bantul Wonokromo Pleret. Nasir (2001) in his book "Ideology of Muhammadiyah movement" describes the NU and Muhammadiyah conflict that occurred in Pasuruan, Situbondo, Gresik, Sidoarjo, Bondowoso, Banyuwangi and Tuban.

\section{Conclusions and Suggestions}

\subsection{Conclusions}

1). The relationship of good communication between superiors and subordinates, subordinates to superiors, and between subordinates in an organization is very positive about the existence of an organization. Honesty, openness and togetherness, are the factors that create a good organizational climate.

2). Good communication within an organization will establish a positive communication climate. Organizational communication climate that is positive can boost productivity of work in an organization, thereby further facilitate the achievement of organizational goals.

3). Organization of the subjects have succeeded in creating a positive climate for the organization of communication, both internal and external communication climate, among others through communication bil wisdom, communication with the spirit of brotherhood and communications on behalf of his fellow villagers, so as to maintain its existence, developing programs, and participate active in rural development.

\subsection{Suggestion}

1). Climate organizational communication need to be developed properly, because of organizational problems is a problem of communication. Its development can be started from honesty, openness, mutual respect.

2). Climate communication good organization to be promoted, in order to achieve harmonization within the organization.

3). Climate of good internal communication needs to be developed first, because it can be a precondition of the initial capital or external communication climate that supports the movement of the organization.

\section{References}

Arifin B. (2015). Influence Factors on Performance Employee Satisfaction Communication. Journal of Management \& Organization Studies, 2(1), 16-34.

M. As'ad Psychology Industri. Edisi (2001). Fourth, Fifth Matter. Yogyakarta (ID): Liberty. Chusnan, M. (2013). Sufism Muhammadiyah: Spiritual Leadership Immersion AR. Fakhruddin. Jakarta (ID): Dome of Science. 


\section{Macrothink}

Journal of Social Science Studies

ISSN 2329-9150

2017, Vol. 4, No. 1

Creswell, J. W. (2012). Research Design Approach Qualitative, Quantitative, and Mixed. Yogyakarta (ID): Student Library.

Data Charitable Enterprises Muhammadiyah. (2016). Retrieved March 20, 2016, from http://www.muhammadiyah.or.id/content-8-det-amal-usaha.html

Davis, K., \& Newstrom, J. W. (2003). Behavior in Organizations. Volume 2. Jakarta (ID): Erland.

OU Effendy. (1987). Communication and Modernization. Bandung (ID): Alumni.

Habermas, J. (2007). The Theory of Communicative Actions II: Critique of Ratio functionaries. Tr. Nurhadi. Yogyakarta (ID): Creative Discourse.

Haedar, N. (2003). Guidelines Islami Life Residents Muhammadiyah. Yogyakarta (ID): Suara Muhammadiyah.

Harmoko. (1985). Communication Connect Rasa. Jakarta (ID): Pustaka Sinar Harapan.

Hashim, M. W. (2000). It is important, Optimizing Social Role of Muhammadiyah Through Branch. Yogyakarta (ID): BC Library.

Herdianto, W. (2010). Five Effective Communication Law. Retrieved October 15, 2013, from http:/wanvisioner.blogspot.com/2010/01/reach-lima-hukum-komunikasi-efektif.html

Jablin, F. M. (1987). Handbook of Organization Communication: An Interdiciplinary Perspective. Newbury Park (GB): Sage Publications.

Moleong, L. J. (2005). Qualitative Research Methodology. Revised Edition. Bandung (ID): Teens Rosdakarya.

Pace, R. W., \& Faules, D. F. (2000). Organizational Communication. Translation Deddy Mulyana. Jakarta (ID): Rineka Reserved.

Pangumpia, F. (2013). Influence of organizational climate on employee productivity at Bank Prisma Dana Manado. Journal Acta Diurna, 2(2), 1-6.

Putnam, L. (1983). The Interpretative Perspective: An Alternative to Functionalism. California (US): Sage

Rahardjo, S. (2007). Conflict between NU and Muhammadiyah 1960-2002 (Wonokromo Pleret Case Study in Bantul, Yogyakarta. [Thesis] UIN Sunan Kalijaga, Yogyakarta: Faculty of Adab.

Royyani. (2011). Overview Ranting Muhammadiyah Plompong From Time To Time (A Hope and Reality). Brebes (ID): PRM Plompong

Sugiyono. (2010). Qualitative and Quantitative Research Methods RND. Bandung (ID): Alfabeta.

Yoanne, B. (2013). Effects of organizational climate PT Djatim Super Cooking Oil Surabaya on employee performance. Journal of E-Communication Petra Christian University, 1(3), $2-6$. 


\section{Copyright Disclaimer}

Copyright for this article is retained by the author(s), with first publication rights granted to the journal.

This is an open-access article distributed under the terms and conditions of the Creative Commons Attribution license (http://creativecommons.org/licenses/by/3.0/). 